\title{
Study on Import and Export-Led Economic Growth: Cases of Botswana, Namibia, South Africa, and Zimbabwe in Southern Africa
}

\author{
Kudzai Shamaine Tivatyi', Jian Min Shou1*, Kodjo N'Souvi ${ }^{2}$ \\ ${ }^{1}$ School of Economics \& Management, Shanghai Maritime University, Shanghai, China \\ ${ }^{2}$ College of Economics and Management, Shanghai Ocean University, Shanghai, China \\ Email: ‘jmshou@shmtu.edu.cn, skudzii@yahoo.com
}

How to cite this paper: Tivatyi, K. S., Shou, J. M., \& N'Souvi, K. (2022). Study on Import and Export-Led Economic Growth: Cases of Botswana, Namibia, South Africa, and Zimbabwe in Southern Africa. Open Journal of Business and Management, 10, 670-700.

https://doi.org/10.4236/ojbm.2022.102038

Received: January 18, 2022

Accepted: March 6, 2022

Published: March 9, 2022

Copyright $\odot 2022$ by author(s) and Scientific Research Publishing Inc. This work is licensed under the Creative Commons Attribution International License (CC BY 4.0).

http://creativecommons.org/licenses/by/4.0/

\begin{abstract}
This study aims to investigate the relationship between exports, imports and economic growth of a sample of four countries in Southern Africa for the period 1980-2019. In doing so, we check whether the Export-Led growth $(E L G)$, Import-Led Growth ( $I L G)$, Growth-Led Export (GLE) and growth-led import (GLI) propositions hold in four Southern African economies, namely Botswana, Namibia, South Africa and Zimbabwe. Specifically, the present study tries to 1) understand to which extent imports, exports and economic growth are correlated in the short and long run in Botswana, Namibia, South Africa and Zimbabwe; 2) assess the effects of imports and exports on the economic growth in each of these countries. To this end, we used time series data, covering the period 1980 to 2019. In doing so, the co-integration tests, Vector Autoregressive " $V A R$ " model (for South Africa) and vector error correction models "VECM" model (for Botswana, Namibia and Zimbabwe) then Granger causality tests are applied to investigate the relationship between the variables. The results show that both short run and long run relationships exist among these variables. On the one hand, our findings failed to validate the export-led growth hypothesis for South Africa in the long-run but provided support for the exports-led growth hypothesis in the short-run. The analysis finds prominent evidence of bidirectional causality between exports and growth for Botswana, Namibia, and Zimbabwe in the long run. On the other hand, a suggestive evidence of unidirectional causality running from growth to imports was found in the case of Botswana, Namibia and South Africa. In addition, bidirectional causality between exports and imports was validated by Zimbabwe case study. Key implications are that the exports development could create employment opportunities and other spillovers. Policy-makers should improve and strengthen the competiveness of export sector. Moreover, Na-
\end{abstract}


mibian case study confirmed the imports-led growth hypothesis in the longrun, implying that an import liberalization policy could be useful for economic growth in Namibia.

\section{Keywords}

Economic Growth, Export-Led Growth, Import-Led Growth, VECM, Co-Integration

\section{Introduction}

Understanding the causality between imports, exports and economic growth is important for the formulation of trade policies toward a country's economic and social development. Imports and exports are often regarded as key enablers and drivers of economic development in developing countries (Utonga \& Dimoso, 2019). This interaction has traditionally been one of the central concerns of development economics. For instance, countries may prefer to adopt the importsubstitution trade policy if import trade does not contribute to economic growth. In some instances, a country may opt for exports promotion for its development. While, adopting the import substitution trade policy may not necessarily translate to economic growth, exports promotion strategy, as a priority is no guarantee of growth either. Priority or preference for one or the other of these development strategies through international trade should be based on individual national situations of the countries concerned.

Numerous studies have examined the relationship between imports, exports and economic growth (e.g. Abdulla \& Ali, 2019; Aluko \& Adeyeye, 2020; Reddy, 2020; Shah et al., 2020). The findings of most of these studies have no consensus, particularly the direction and potency of the causal impact of imports and exports on growth. The existence of conflicting findings in the literature highlights the significance of a study to determine the relationship between imports, exports and growth, as the results cannot be generalized to any country due to different country characteristics used in the investigations. Similar investigations, to the best of knowledge, have not been done for countries such as Botswana, Namibia, South Africa, and Zimbabwe in comparison terms. A comprehensive study assessing the extent of imports and exports on growth in these four countries may be more insightful.

Against this background, the general objective of this study is to examine the causality dynamics between imports, exports and economic growth in a time series modelling approach, for a sample of four countries. Specifically, the present study aims to: 1) determine whether imports, exports and economic growth are correlated in a long run or a short run in Botswana, Namibia, South Africa and Zimbabwe; 2) determine if imports and exports affect positively or negatively economic growth in Botswana, Namibia, South Africa and Zimbabwe. 
The existence of conflicting findings in the literature highlights the significance of a study to determine the relation between imports, exports and growth, as the results cannot be generalized to any country due to different country characteristics used in the investigations. This study will be particularly useful to policymakers in understanding the short- and long-run causality dynamics between imports, exports and economic growth in the Southern African countries under investigation. It is vital for policymakers to identify the main variables of imports and exports that will give life to economic growth in these Southern countries so that they can be able to take appropriate actions to be undertaken and assess their effects with accuracy. Moreover, this study will indicate to which extent certain variables affect economic growth so that any policy actions would be undertaken with predictable effects. Furthermore, this research is significant because it will add up to the limited available literature on the economy of the countries under investigation by providing new information.

In addition to the introduction, the rest of the paper is organized as follows. Section 2 entitled literature review will present an overview of total imports, exports and trends in economic growth of the countries under investigation and reviews the literature of empirical on ELG, GLE and ILG as well. Section 3 " $M a$ terials and methods" outlines the theoretical framework, the econometric model and data collection. Empirical results are reported in Section 4, while Section 5 discusses such findings by comparing them to that of previous studies. Finally, Section 5 provides the conclusion and policy implications.

\section{Literature Review}

\subsection{Overview of Total Imports of Botswana, Namibia, South Africa and Zimbabwe}

Over the last thirty years, economies of Southern African countries have experienced total production characterized by heavy dependence on natural resources and low added value. In the case of Botswana, Namibia, South Africa and Zimbabwe, imports over the period 1980-2019 have shown a near rising trend (Figure 1). Foreign trade structure of these countries remains not very diversified. Apart from South Africa, none of the countries in the sub-region produce goods suited to neighboring countries demand, hence the low level of intra-regional trade and complementarity linkages among them. Except some cases where the value has decreased relative to previous year, imports of goods and services by Botswana, Namibia, South Africa and Zimbabwe have been on an upward trend for almost four decades (Figure 1). Recent statistics for top imports structure into these countries in 2020 is shown in Table 1.

Botswana graduated from being among the poorest in Africa at the time of independence in 1966 to an upper middle-income country within a period of three decades with an annual economic growth, which, is strongly influenced by mineral resources, particularly diamonds (Siphambe et al., 2005). It outperformed 


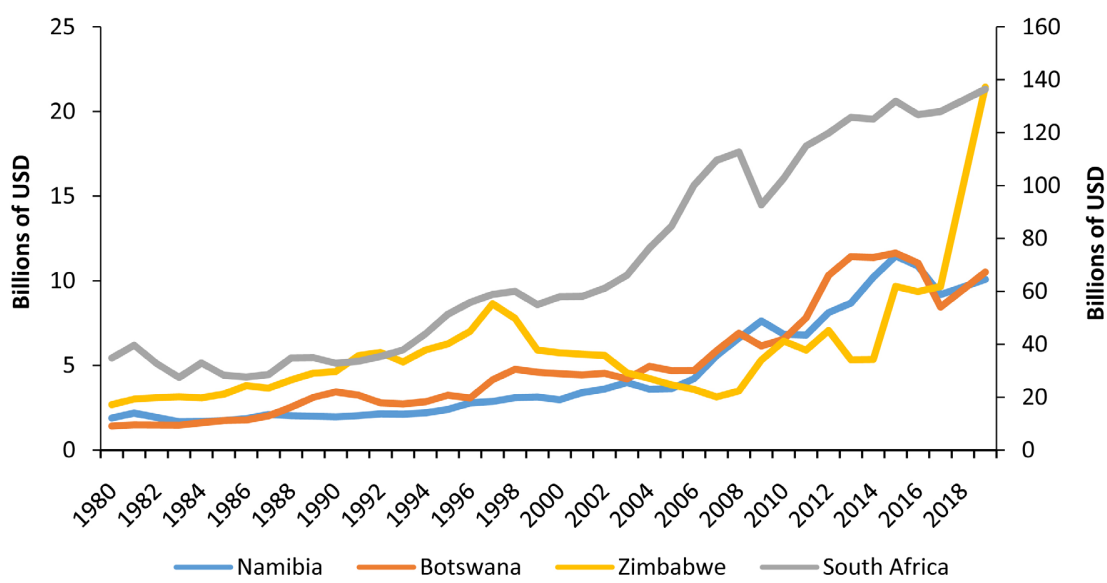

Figure 1. Trends in import values of goods and services 1980-2019 (billions of USD). Source: Authors, based on WDI database, 2020.

Table 1. Countries' imports composition for Botswana, Namibia, South Africa and Zimbabwe.

\begin{tabular}{|c|c|c|c|c|c|}
\hline \multirow{2}{*}{$\begin{array}{l}\text { HS } \\
\text { code }\end{array}$} & \multirow[b]{2}{*}{ Products label } & \multicolumn{4}{|c|}{ Share in the countries' imports (\%) } \\
\hline & & Botswana & Namibia & $\begin{array}{l}\text { South } \\
\text { Africa }\end{array}$ & Zimbabwe \\
\hline 71 & $\begin{array}{l}\text { Natural or cultured pearls, } \\
\text { precious stones, metals, }\end{array}$ & 30 & 5 & 22 & 0 \\
\hline 27 & Mineral fuels, mineral oils & 13 & 8.42 & 8.09 & 16.1 \\
\hline 87 & $\begin{array}{l}\text { Vehicles other than railway } \\
\text { or tramway rolling stock }\end{array}$ & 8.41 & 5.18 & 9.83 & 0 \\
\hline 84 & machinery and mechanical appliances & 6 & 6.21 & 5.79 & 12.7 \\
\hline 85 & $\begin{array}{l}\text { Electrical machinery and } \\
\text { equipment and parts thereof }\end{array}$ & 5.13 & 3.58 & 1.76 & 4.47 \\
\hline 10 & Cereals & 2.22 & 0 & 0 & 10.3 \\
\hline 30 & Pharmaceutical products & 1.91 & 0 & 0 & 3.73 \\
\hline 39 & Plastics and articles thereof & 1.86 & 2.51 & 0 & N/A00 \\
\hline 73 & Articles of iron or steel & 1.81 & & 0 & 3.51 \\
\hline
\end{tabular}

Source: Authors' compilation based on UN COMTRADE 2020 database.

every other country in the world in terms of per-capita income growth from 1965 to 1998 (Acemoglu et al., 2001).

Since 2005, South Africa has experienced a rise in its foreign trade for thirteen consecutive years. With an increasing trend in imports both in volume and value terms, the country's foreign trade has remained much the same over the years. Imports are centered around five items, which account for nearly total sales and two-thirds purchases, respectively. As in 2016 for example, China, the United States and Germany are its top three customers and suppliers. China occupies 
the first position in terms of both exports and imports for South Africa. On the imports side, the country mainly purchases 1 ) machinery and electrical appliances (23.4\% of total imports in 2017$), 2)$ mineral products $(+15.1 \%$ of total) and 3 ) chemical industry products $(+10.9 \%)$,

Since 1980, except for 1997 to the end of the first half of 2000s, Zimbabwe has been characterized by an increasing trend in imports in terms of both value and volume (Bonga et al., 2015). Major imports into Zimbabwe for the period 1980-2019 have been dominated by low-medium income economies and high-income economies. As origins of imports into Zimbabwe, South Africa is still its main trading partner. The country's top import categories in 2019 were iron \& steel, tobacco, sugar, and coffee \& tea totaling USD 20 million, USD 10 million, USD 7 million, and USD 5 million, respectively, while the composition of its imports for major products in 2020 is summarized in the above Table 1.

\subsection{Overview of Total Exports by Botswana, Namibia, South Africa and Zimbabwe}

Like most developing countries to which this is particularly relevant, Southern African countries have a large share of exports of raw materials and commodities in their GDP. Figure 2 shows the trend export values of goods and services by the four countries under investigation.

Indeed, from 1995-2005, the mining sector represented an average of 34.5 percent of Botswana's GDP, with diamonds constituting nearly 94 percent of the sector's total exports. In 2014 , it accounted for $85.9 \%$ of the country's total exports, up from $83.5 \%$ the previous year. Similarly, in 2019, diamonds still dominated Botswana's principal exports with a $93.4 \%$ share of the country's principal exports (Statistics Botswana, 2019).

In the case of Namibia, the export Development Strategy of 1998 prioritized the processing of minerals, mariculture and agriculture. The emphasis of this strategy was to ensure that Namibia moves away from exports of primary to

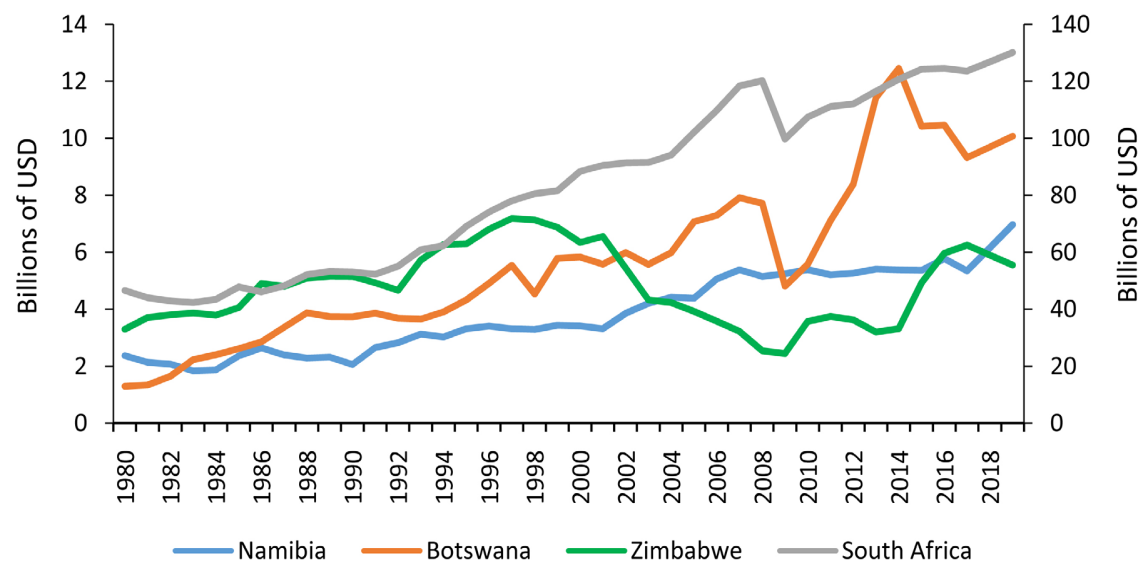

Figure 2. Trends in exports value 1980-2019 (billions of USD). Source: Authors, based on WDI database, 2020. 
processed or secondary products. Other sectors such as tourism, which have the potential to generate high income, are also considered as priorities. Ogbokor and Meyer (2016) analyzed the relationship between foreign trade and economic growth in Namibia to demonstrate a positive relationship and co-integrating relationships between the variables. Simasiku and Sheefeni (2017) also used a time series quarterly data spanning 1990-2014 to analyze the relationship between agricultural export and economic growth in Namibia. They found that the agricultural exports have a positive and insignificant effect on economic growth while non-agricultural exports have a positive and significant effect on GDP in Namibia.

In Zimbabwe, although the trade surplus diminished in 1979 thanks to the rise in oil prices, the value of exports still outpaced that of imports. In the 1980s, Zimbabwe showed slow but steady growth in its trade surplus, as its unusually high level of export diversity helped a lot in adapting in the world demand for its commodities. Zimbabwe's mining sector remains predominant in its exports, accounting for $66.0 \%$ of the total exports value, followed by tobacco, agriculture and manufacturing that represent $18.9 \%, 9.4 \%$ and $5.1 \%$, respectively. Thus, mining, agriculture and tobacco combined account for almost $95 \%$ of exports value.

In case of South Africa with an increasing trend in imports both in volume and value terms, the country's foreign trade has remained much more the same over the years. Its sales consist mostly of mining products including mineral products $(+25.1 \%$ of total exports in 2017$)$, precious stones $(+16.7 \%$ of total) and base metals $(+11.8 \%$ of total).

\subsection{Trends in Economic Growth of Botswana, Namibia, South Africa and Zimbabwe}

Economic growth is not always steady. Seemingly small differences in yearly GDP growth can lead to large changes in GDP when compounded over time. Figure 3 depicts the movements in Botswana, Namibia, South Africa and Zimbabwe's economic growth, measured by changes in their annual GDP. From 2000 to 2017, the average pace of economic growth in the region (3\%) has been much lower than that of other regions in Africa.

Botswana has experienced an extraordinary change in economic growth since it gained independence. In the second half of 1960s, Botswana was categorized as a least developed country (LDC) with a GDP per capita of around US\$ 70 (AfDB, 2013). Through subsequent good governance, sound macroeconomic policy, and the discovery of diamonds in the 1970s it has transformed itself into an upper middle-income country with a GDP per capita of US\$ 9900 by 2011 (Feenstra et al., 2013). Until 1998, Botswana like other developing countries pursued an import substitution strategy (Hur \& Park, 2012). However, with the Industrial Development Policy, trade liberalization has been one of the flagship initiatives of the development agenda with the implementation of export-led 


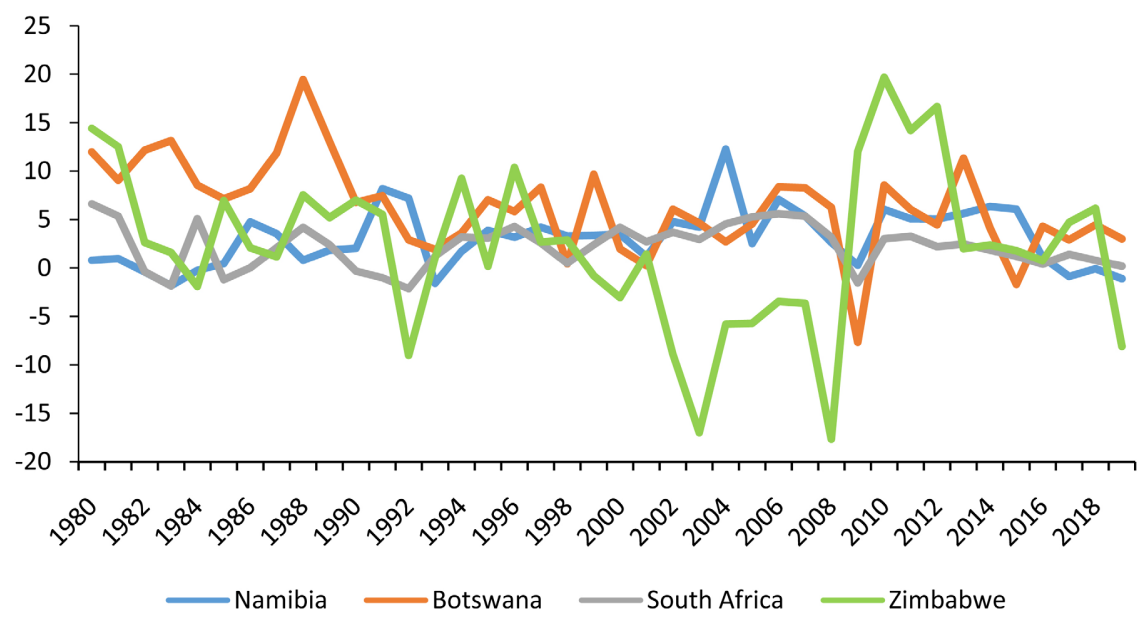

Figure 3. GDP growth (annual \%)-Botswana, Namibia, South Africa and Zimbabwe 1980-2019. Source: Authors, based on WDI database, 2020.

growth strategies. Botswana's economy contracted by an estimated $8.9 \%$ in 2020 due to the global pandemic situation, after growing by $3.0 \%$ in 2019. Real GDP growth is projected to recover to $7.5 \%$ in 2021 and $5.5 \%$ in 2022 , based on a revival in domestic demand (AfDB, 2021).

South Africa also experienced irregular trend in its growth over the time. The country made considerable strides to improve growth and wellbeing of its citizens since its transition to democracy in the mid-1990s. However, the progress has stagnated in the last decade. Its economy contracted by $7 \%$ in 2020 , representing the biggest annual fall in economic activity the country has seen since at least 1946 (Stats SA, 2021). The GDP is expected to rebound again by $3 \%$ in 2021 (World Bank, 2021).

In Zimbabwe after a period of sustained growth, the macroeconomic situation has deteriorated sharply over the years, and since 1999 the country has been facing a deep crisis. For the last decade, Zimbabwean GDP has followed a saw tooth pattern. For instance, $6.8 \%$ in 2011, compared to $9 \%$ in $2010,4.4 \%$ in 2012 , before recovering to $5.5 \%$ in 2013 . The country's real GDP growth is driven by sectors such as agriculture, mining, manufacturing and transportation. Zimbabwe's economy entered into a period of recession, contracting $6 \%$ and $8 \%$ in 2019 and 2020, respectively.

\subsection{Literature on Imports, Exports and Economic Growth}

\subsubsection{Theoretical Review}

Every single country quite rightly aspires to economic growth, which is fundamental to any form of development and societal wellbeing (Sulaiman \& Saad, 2009). Achieving such economic growth in a sustainable way is one of the major targets of many countries. The benefits of international trade on economic growth were traced since classical economists such as and Adam Smith and David Ricardo who believe that free trade leads to economic prosperity. According to the 
Neo-classical theory the level of exports and imports plays a significant role in determining a country's economic and social development (Vijayasri, 2013). Additionally, exports can create and boost investment opportunities through inflows of foreign exchange that are also necessary to import goods and services.

Several literatures argued that positive productivity effects estimated by export-led growth hypothesis do not necessarily occur in developing countries. This is because most developing countries are heavily dependent on exports of primary commodities which sector does not have enough linkages and spillover into the economy (Herzer, 2007). Such a situation is not conducive for these economies to develop competitive manufacturing sectors which have many externality factors required for sustainable growth.

According to the Heckscher-Ohlin model of international trade, a country will benefit by specializing in the production and exports of commodities that intensively use production factors that the country is abundant in (Jones, 2008). Accordingly, many Africa countries, which are labor and natural resource-abundant should export labor- and natural resource-intensive primary commodities and import capital-intensive products (Wood \& Mayer, 2001).

Imports boost productivity through their competitive impact. Competitive pressure fosters within firm improvements through reorganization and elimination of inefficiencies and provides incentives to innovate (Grossman \& Helpman, 1991). The heterogeneous firm models, such as Melitz (2003) and Andrew et al. (2003) also show that import competition leads to an average productivity increase as most productive firms expand while the less productive domestic firms exit. In addition, imports provide firms with access to better, cheaper, and domestically unavailable inputs and equipment. As a result, they stimulate productivity and reduce production costs making the production of new goods both possible and profitable (Rivera-Batiz \& Romer, 1991). Imports allow access to foreign technology because foreign technology is embodied in imported inputs and equipment (Coe \& Helpman, 1995). Quantifying their impact may require doing crosscountry analysis.

\subsubsection{Empirical Review}

Jung and Marshall (1985) is one of the pioneer and famous works that investigates the causal relationship between exports and economic growth. They used Granger causality test on each of the 37 developing economies covered by the study to point out evidence in favor of export promotion preceding economic growth only in case of Indonesia, Egypt, Costa Rica and Ecuador.

Ahmed and Kwan (1991) find no evidence in support of causality from exports to economic growth in their study on a sample of 47 developing African economies. The authors revealed weak causality from growth to exports for some countries, similar results that were found later by Dodaro (1991) for a very large sample of developing countries. Some other studies (e.g. Shan \& Sun (1998), 
Awokuse (2005)) used Toda and Yamamoto (1995) procedure and found evidence of bi-directional causality between export and growth.

Lin and Li (2003) re-examine the effect of international trade to the Chinese economic growth. Their results showed the existence of uneven positive relationship between export and economic growth. Velnampy and Achchuthan (2013) analyzed the effects of imports and exports on Sri Lanka's economic growth and revealed the existence of a strong relationship between imports and exports. In addition, their findings showed that both between imports and exports possess a significant effect on the Sri Lanka economic growth. The study by Hussain and Saaed (2014) which scrutinized the nexus of economic growth, imports and exports in Saudi Arabia, demonstrated the presence of a long-run relationship, though the absence of causality, among these three variables.

Empirically, Beny and Cook (2009) found a positive correlation between natural resources and economic growth of African countries during the period 1995-2005. A study of manufacturing exporting firms in selected SSA countries shows that exporting firms became more productive, and paid higher wages after they entered the export market as compared to non-exporting firms (Van Biesebroeck, 2005), pointing out that for some countries, a gain from exporting may exist when they develop an export-oriented manufacturing sector (Bigsten et al., 2004). Likewise, Arodoye and Iyoha (2014) found that exports lead to economic growth. Werner Kristjanpoller and Olson (2014) demonstrated that exports drive growth of gross domestic product (GDP). Their findings for eight countries, five countries and one country support the ELG theory, and the ILG theory, respectively. In addition, they found that in theory, ELG and ILG cannot exist simultaneously in a country. In his study on the crucial role of imports in a trade-led growth strategy, Hallaert (2014) pointed out that imports contribute to growth directly by stimulating productivity and indirectly by increasing export performance.

Saaed and Hussain (2015) investigated the impact of imports and exports on the economic growth of Tunis over the period 1977-2012. The study used Granger causality and Johansen co-integration approach for long run relationship. Using Augmented Dickey-Fuller (ADF) and Phillip-Perron (PP) stationarity test, they found that economic growth Granger cause import, indicating that there is unidirectional causality between exports and imports and between exports and economic growth. These results provide evidence that growth in $\mathrm{Tu}$ nisia was propelled by a growth-led import strategy as well as export led import. In contrast, the study of Mehta (2015), which analyzed the relationship between imports, exports and economic growth in India, revealed that there is no long-run relationship among these variables. The granger causality test results indicated that GDP causes exports growth, meanwhile exports do not lead to economic growth. No causation was found between economic growth and imports.

Hassan and Murtala (2016) explored market size and export-led growth hy- 
potheses for Malaysia. Their study finds evidence of unidirectional causality by pointing out that economic growth drives exports, affirming growth-led exports hypothesis. Lam (2016) also analyzed the causality between real GDP and real export of goods and services for Indonesia, Malaysia, Thailand and the Philippines and found a bidirectional causal relationship between exports and economic growth. Bakari and Krit (2017) investigates the relationship between exports, imports, and economic growth in Mauritania using annual data that were collected from the reports of World Bank for the periods between 1960 and 2015. They found that exports have a positive effect on economic growth. However, imports have a negative effect on economic growth. In addition, their results showed that there is unidirectional causality between imports and economic growth. Taniguchiy (2018) studied the effect of an increase in imports from china on local labor markets in Japan. He found evidence supporting that the growth in imports from China positively affected manufacturing employment growth at the prefecture level in Japan.

Manwa et al. (2019) investigated the possible link between trade liberalization and economic growth for five Southern African countries including Botswana, Namibia and South Africa, over 30 years. Their results revealed evidence supporting that trade liberalization has had a positive impact on the economic growth in the countries under investigation. Jan et al. (2019) studied the impact of exports and imports on economic growth of Pakistan. They used a time series data that cover the period from 1981 to 2016 to demonstrate that exports have a positive impact on GDP growth in the long run, while imports though insignificant, were negatively correlated to the GDP of Pakistan. Abdulla and Ali (2019) investigated the causal relationship between exports, imports, and economic growth in Iraq. They reported that both exports and imports positively affect Iraqi's economic growth in the long run.

Aluko and Obalade (2020) examined the nexus between imports and economic growth for a sample of 26 African countries for the period 1990-2015 within the neoclassical production function framework. Using the Toda-Yamamoto Granger non-causality test, their empirical results indicate that there is absence of causality between imports and economic growth in more than half of the countries in the sample, providing therein evidence that causality is absent from imports to economic growth. Similarly, Aluko and Adeyeye (2020) have tested for causality between imports and economic growth in 41 African countries. Their findings suggest that, the neutrality hypothesis is valid in the short-and long run periods for most countries, apart from the unidirectional causality running from imports and economic growth, and unidirectional causality running from economic growth to imports for few countries.

Shah et al. (2020) reviewed the relationship among capital formation, economic growth, exports and imports in Pakistan, based on time series data from 1976 to 2015. Their findings reveal that exports, imports, real GDP and gross fixed capital formation have a long run relationship. They further pointed out 
that GDP does not stimulate exports and imports while exports and imports promote growth in the long run.

A study by Reddy (2020) examined the relationship between exports, imports and economic growth in India, for the period 1980-2019. The results revealed that there is a unidirectional causality from economic growth to exports; exports to economic growth; exports to imports; imports to economic growth in the short-run. In the long-run, author confirmed the existence of a bidirectional causality relationship between economic growth and exports; and between exports and imports. Consequently, one may conclude both exports and imports increase economic growth in India. Likewise, Maitra (2020) explored the import led growth assumption in India for the post-reform period. His analysis found prominent evidence supporting ILG hypothesis, both in the short run and in the long run, demonstrating that import is a significant bearing of India's economic growth.

Alam and Sumon (2020) examined the causal relationship between economic growth and trade openness for 15 Asian countries over period 1990-2017. They have applied panel co-integration and causality approaches to point out the presence of co-integration between variables. In addition, their findings reveal bidirectional causality between economic growth and trade openness for countries under investigation.

Overall, the above literature documents that there is no specific research, which has investigated to which extent exports, imports and economic growth in major exports countries are associated. This therefore inspired us to empirically study the link between imports, exports and economic growth in Southern African countries, given the ability to quantify the effects of exports and imports on the economic growth of countries or of a region is important for government officials, and traders whose decisions and actions have economic repercussions that they ought to understand before they act.

\section{Materials and Methods}

\subsection{Data}

\subsubsection{Study Area}

This study focuses on four countries located in southern Africa: Botswana, Namibia, South Africa and Zimbabwe (Figure 4). A country in the center of Southern Africa, Botswana's territory is roughly triangular with approximately $965 \mathrm{~km}$ from north. River courses and an old wagon road mark its eastern and southern borders. Botswana is bounded by Namibia to the west and north, Zambia and Zimbabwe to the northeast, and South Africa to the southeast and south. As for Namibia bordered by the Atlantic Ocean to the west, it shares land borders with Zambia and Angola to the north, Botswana to the east and South Africa to the south and east. As its name indicates, South Africa is the southernmost country on the African continent. It is located along the South Atlantic and Indian Oceans to the South, bordered to the north by the neighboring countries of 


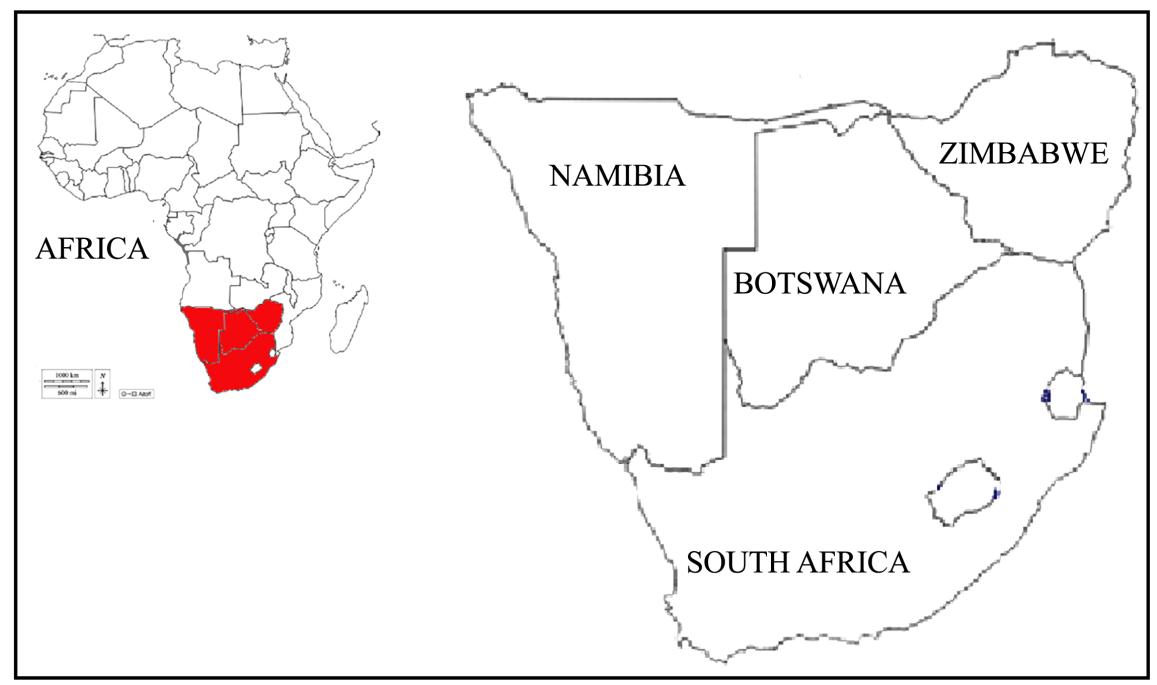

Figure 4. Map of Eastern Africa showing the study area. Source: https://d-maps.com/continent.php.

Namibia, Botswana, and Zimbabwe; and to the east and northeast by Mozambique and Eswatini. Typically, Zimbabwe, a landlocked country in Southern Africa that shares border on the south with the Republic of South Africa, is bounded on the southwest and west by Botswana, on the north by Zambia, and on the northeast and east by Mozambique.

This region was selected because the countries under investigation are all members of the Southern African Development Community (SADC). As such, they can realize benefits from the ties of their territorial proximity and advantages of the integration through the promotion of regional trade. They have been signing some agreements or economic cooperation for their economic development. For instance, in 2008, South Africa, Botswana, Namibia and Zimbabwe held a legal joint sale behind closed doors in Namibia of seven tons of ivory, earning more than US\$1.18 million, to Chinese and Japanese bidders.

\subsubsection{Data Source}

This study was conducted using information from different secondary sources. The data used mainly come from the World Bank's World Development Indicator (WDI) database 2019, spanning from 1980 to 2019. The choice of the study period is based on data availability. Some information were gathered through scientific research and grey literature published in various forms (e.g. peer-reviewed journals, periodicals and government gazettes). Other information was collected through the available online database by using the following keywords "imports", "exports", "imports led-growth theory", and "exports led-growth theory". In addition, information was also collected through visiting different relevant institutes, for example Ministry of Industry and Commerce of Zimbabwe, Ministry of Investment, Trade and Commerce Botswana, and that of Namibia and South Africa, respectively. The data set consists of observations for GDP, exports of goods and services, and imports of goods and services. 


\subsection{The Model}

The causality dynamics between imports, exports and economic growth may vary over time, due to business cycles, and policy and structural changes. A large number of studies analyzed the Export-Led Growth (ELG) hypothesis and Import-Led Growth using different econometric procedures ranging from simple OLS to multivariate co-integration; however, previous empirical studies have produced mixed and conflicting results on the nature and direction of the causal relationship between export growth and output growth. Thus, it is important to account for the possible variations in the causality dynamics between imports, exports and economic growth over time with the aid of a frequency domain approach to Granger causality testing. The present study employs the co-integration and error correction modeling technique as the estimation methodology.

\section{Model Specifications}

Following Deme (2002), Sato and Fukushige (2007), and Katircioglu et al. (2010), ILG and GLI hypotheses can be examined using the causal link between imports and economic growth as shown in the following equations:

$$
\begin{aligned}
& Y_{t}=\theta_{0}+\theta_{1} M_{t}+\psi_{t} \\
& M_{t}=\varphi_{0}+\varphi_{1} Y_{t}+v_{t}
\end{aligned}
$$

where $Y$ and $M$ indicate economic growth (GDP) and imports, respectively, and $\theta_{0}, \theta_{1}, \varphi_{0}$, and $\varphi_{1}$ denote the parameters to be estimated; $t$ stands for time period $(t=1, \cdots, T), \psi_{t}$ and $v_{t}$ are the error terms. On the other hand, ELG and GLE hypotheses, which investigate the causal relationship between exports and economic growth can be written as follows:

$$
\begin{gathered}
X_{t}=\beta_{0}+\beta_{1} Y_{t}+v_{t} \\
Y_{t}=\alpha_{0}+\alpha_{1} X_{t}+\psi_{t}
\end{gathered}
$$

where $\beta_{0}, \beta_{1}, \alpha_{0}, \alpha_{1}$ are the coefficients, $\psi_{t}$ and $v_{t}$, the error terms.

Using variables in the global market such as present consumption, production, investment, and rate of interest, Husted (1992), derived the theoretical relation between export and import by starting with the current budget constraint as follows:

$$
C_{t}=Y_{t}+B_{t}-I_{t}(1-r) B_{t}
$$

where $C_{t}, Y_{t}, I_{t}$, and $r$ are the present consumption, production, investment, and rate of interest, respectively. By imposing sufficient structures and the constraints to the previous equation, the following testable empirical model can be obtained:

$$
X_{t}=\lambda_{0}+\lambda_{1} Y_{t}+\psi_{t}
$$

Following Arize (2002), Equation (6) can be rewritten as:

$$
M_{t}=\gamma_{0}+\gamma_{1} X_{t}+\mathrm{v}_{t}
$$

where $\lambda_{0}, \lambda_{1}, \gamma_{0}$, and $\gamma_{1}$ are the parameters to be estimated; $t$, the time pe- 
$\operatorname{riod}(t=1, \cdots, T), \quad \psi_{t}$ and $v_{t}$ the error terms.

If there is a co-integration between exports, imports and economic growth variables, the international market budget constraint is thus stable, implying a bidirectional relationship and their related coefficients are equivalent to one or more than one (Hye, 2012). In the present study, we first check the stationary properties. To this end, we employed the Augmented Dickey-Fuller (ADF) as unit root test to check the stationary process. The unit root test is applied to examine if the null hypothesis has a unit root or not. The lag length selection criteria is based on Akaike Information Criterion (AIC). The ADF test can be written in the $\operatorname{AR}(p)$ process as:

$$
\Delta Y_{t}=\mu+\lambda_{t}+\varphi Y_{t-1}+\sum_{i=1}^{p} \alpha_{i} \Delta Y_{t-1}+\varepsilon_{t}
$$

where $\Delta$ is the first difference operator, $Y$ is the variable, $\mu$ is an intercept, $\lambda_{t}$ is a linear time trend, $p$ is the order of augmentation of the test, and $\varepsilon_{t}$ is the error term. The stationary variable is said to be integrated of order one denoted by $I(1)$.

In the second step, we will examine the long-run relationship between the variables in each economy; the Johansen-Juselius co-integration technique model is used to express the co-integration as implemented. One advantage of the Johansen-Juselius co-integration technique model is that it offers one advantage over the traditional methods. It is applied to the order of integration of the regressors purely $I(1)$. It should be noticed that the co-integration technique is appropriate for estimating the long-term relationship between exports, imports, and economic growth,

$$
\begin{aligned}
& \lambda_{\text {trace }}(r)=-T \sum_{i=r+1}^{n} \ln \left(1-\hat{\lambda}_{i}\right) \\
& \lambda_{\text {max }}(r, r+1)=-T \ln \left(1-\hat{\lambda}_{i+1}\right)
\end{aligned}
$$

where $\lambda_{i}$ stands for the estimated characteristic $T$, the number of observations that can be used.

This paper is based on the following hypotheses to test the causality and co-integration between GDP, export and import:

1) There is bi-directional causality between GDP growth and export and import.

2) There is unidirectional causality between the three variables.

3) There exists a long-run relationship between GDP and export and import.

Equations (1) and (2) explain that both $X$ and $Y$ stand for exports and economic growth. Based on the international trade literature reviewed, we conducted this study with the assumption that export expansion and high levels of imports stimulate growth. Given these assumptions, we expected positive estimates for the coefficients of exports and imports.

\subsection{Data Processing}

Data and information collected were coded and incorporated into computerized 
databases using Excel 2016 to set up tables and figures. Then, Stata 16 econometric software was used for econometric estimates of the ELG, ILG and Johansen-Juselius co-integration models in this study.

\section{Results}

\subsection{Descriptive Statistics}

The descriptive statistics for the variables in this study are provided in Table 2. Such summary statistics show that, from 1980 to 2019, imports of goods and services into the overall four countries under investigation are, on average, USD 22 billion, with South Africa as the biggest importer with USD 71 billion. As for the exports, the four countries had exported, on average, about USD 24 billion over the same period. Again, South Africa is the largest exporter of goods and services in terms of economic value, totaling USD 83 billion. The gross domestic product (GDP), on the other hand, amounts, on the average, USD 77 billion for all the countries sampled, while South Africa's GDP was the highest (USD 292 billion) over the same period. It should be noted that the average annual GDP growth was 3.5\% for the full sample, with Botswana, which is in the lead here, with $6.3 \%$ as average GDP growth within the period 1980 to 2019.

\subsection{Unit Root Test}

In order to avoid spurious regression, the Augmented Dickey Fuller (ADF) test was applied in the models to determine the stationarity of the data. The null hypothesis, $\mathrm{H} 0$ assumes that variables are not stationary or have unit root. The outcomes are presented for Botswana, Namibia, South Africa and Zimbabwe, respectively, as given in Table 3. For each country, the results show that the variable imports, exports and GDP are not stationary at the level but become stationary after the first difference.

We further determine the optimal lags through LR, FPE and AIC, which reveal that for Botswana, three (3) lags need to be used in the VECM or VAR model that we might run in the next step (Table 4).

In contrary to Botswana, two (2) lags should be chosen for Namibia based on the results of FPE, AIC, HQIC and SBIC criteria (Table 5).

As for South Africa, LR, FPE, AIC, HQIC and SBIC indicate that only one lag should be used in the VECM or VAR model that will be running in the next

Table 2. Summary statistics of the variables used for the total sample countries.

\begin{tabular}{cccccc}
\hline Variables & Mean & Std. Dev. & Min & Max & Obs \\
\hline Imports & $2.17 \mathrm{e}+10$ & $3.45 \mathrm{e}+10$ & $1.42 \mathrm{e}+09$ & $1.36 \mathrm{e}+11$ & 160 \\
Exports & $2.44 \mathrm{e}+10$ & $3.73 \mathrm{e}+10$ & $1.29 \mathrm{e}+09$ & $1.30 \mathrm{e}+11$ & 160 \\
GDP & $7.74 \mathrm{e}+10$ & $1.31 \mathrm{e}+11$ & 725.576 & $4.33 \mathrm{e}+11$ & 160 \\
GDP_growth & 3.461283 & 5.318166 & -17.66895 & 19.67532 & 160 \\
\hline
\end{tabular}


Table 3. ADF test results for the unit root.

\begin{tabular}{cccccc}
\hline \multicolumn{2}{c}{ Maximum rank } & Botswana & Namibia & South Africa & Zimbabwe \\
\hline \multirow{2}{*}{ Trace Statistics } & 1 & $15.01^{\star *}$ & $8.41^{\star *}$ & $9.00^{\star *}$ & $25.70^{\star *}$ \\
& 2 & 5.96 & 0.95 & $0.000^{\star *}$ & 5.05 \\
\hline \multirow{2}{*}{ None } & 61.59 & 40.36 & $23.23^{\star *}$ & 11.71 \\
& None & 29.68 & 29.68 & 29.68 & 29.68 \\
& 1 & 15.41 & 15.41 & 15.41 & 15.41 \\
& 2 & 3.76 & 3.76 & 3.76 & 3.78 \\
\hline
\end{tabular}

** $P<0.05$.

Table 4. Selection-order criteria for Botswana.

\begin{tabular}{ccccccccc}
\hline Lag & LL & LR & df & $P$ & FPE & AIC & HQIC & SBIC \\
\hline 0 & -1866.76 & & & & $2.6 \mathrm{e}+41$ & 103.88 & 103.92 & 104.01 \\
1 & -1786.14 & 161.23 & 9 & 0.000 & $4.9 \mathrm{e}+39$ & 99.90 & 100.08 & $100.43^{*}$ \\
2 & -1774.52 & 23.25 & 9 & 0.006 & $4.3 \mathrm{e}+39$ & 99.75 & $100.07^{\star}$ & 100.68 \\
3 & -1764.78 & $19.48^{*}$ & 9 & 0.021 & $4.2 \mathrm{e}+39^{*}$ & $99.71^{*}$ & 100.17 & 101.03 \\
4 & -1757.5 & 14.57 & 9 & 0.103 & $4.9 \mathrm{e}+39$ & 99.81 & 100.40 & 101.52
\end{tabular}

Note: Sample: 1984-2019; number of observations: $36 .{ }^{*}$ indicates the lag order selected by the criterion. LR, FPE, AIC, SBIC and HQIC denote the sequential modified LR test statistic (each test at $5 \%$ level), final prediction error, Akaike information criterion, Schwarz information criterion, Hannan-Quinn information criterion, respectively.

Table 5. Selection-order criteria for Namibia.

\begin{tabular}{ccccccccc}
\hline Lag & LL & LR & df & $P$ & FPE & AIC & HQIC & SBIC \\
\hline 0 & -2387.16 & & & & $9.4 \mathrm{e}+53$ & 132.79 & 132.83 & 132.92 \\
1 & -2267.82 & 238.68 & 9 & 0.000 & $2.0 \mathrm{e}+51$ & 126.66 & 126.84 & 127.18 \\
2 & -2250.73 & 34.18 & 9 & 0.000 & $1.3 \mathrm{e}+51^{*}$ & $126.21^{*}$ & $126.53^{*}$ & $127.13^{*}$ \\
3 & -2241.84 & $17.78^{*}$ & 9 & 0.038 & $1.4 \mathrm{e}+51$ & 126.21 & 126.67 & 127.53 \\
4 & -2235.08 & 13.51 & 9 & 0.141 & $1.6 \mathrm{e}+51$ & 126.34 & 126.94 & 128.05 \\
\hline
\end{tabular}

* indicates the lag order selected by the criterion.

step. The AIC criteria revealed that three (3) lags could be used either in VECM or in VAR model for Zimbabwe.

\subsection{The Long-Run Equilibrium Relationship}

As mentioned in the previous sub-section, co-integration test is necessary conducted to assert whether long run relationship exist in the model; it means that in the present study, co-integration test is needed to be conducted given we have 
no stationary series at the levels, rather the three variables are all first difference stationary. To that end, the hypothesis for each country is stated as: H0: no co-integration equation and, $\mathrm{H1}$ : the series are co-integrated.

For Botswana, the results show that both maximum statistic and trace statistic are greater than their critical values (Table 6), we reject both hypotheses stating there is "one co-integration equation" and "there are two co-integration equations" in the model. This means that we have more than two co-integration equations in the model. In other words, we can reject the null hypothesis stating there is no co-integration in this model; meaning that the series imports, exports and GDP are integrated for Botswana.

In the case of Namibia, the trace test value reveals that there is a maximum rank of one co-integration equation in the model (trace statistic $>5 \%$ critical value). Comparatively, and based on the maximum test value, there are more than one co-integration equation in the model (Table 7).

In the case of South Africa, we fail to reject the null hypothesis of no co-integration among imports, exports and growth based on the maximum test values of Johansen co-integration (Table 8). In other words, there exists no long-run relationship between the three variables in South Africa.

Table 6. Botswana model, Johansen tests for co-integration.

\begin{tabular}{ccccc}
\hline $\begin{array}{c}\text { Maximum } \\
\text { rank }\end{array}$ & $\begin{array}{c}\text { Trace } \\
\text { statistic }\end{array}$ & $\begin{array}{c}5 \% \\
\text { critical values }\end{array}$ & $\begin{array}{c}\text { Maximum } \\
\text { statistic }\end{array}$ & $\begin{array}{c}5 \% \\
\text { critical values }\end{array}$ \\
\hline None & 39.9877 & 29.68 & 22.6925 & 20.97 \\
1 & 17.2952 & 15.41 & 11.2260 & 14.07 \\
2 & 6.0692 & 3.76 & 6.0692 & 3.76 \\
\hline
\end{tabular}

Table 7. Namibia model, Johansen tests for co-integration.

\begin{tabular}{ccccc}
\hline $\begin{array}{c}\text { Maximum } \\
\text { rank }\end{array}$ & $\begin{array}{c}\text { Trace } \\
\text { statistic }\end{array}$ & $\begin{array}{c}5 \% \\
\text { critical value }\end{array}$ & $\begin{array}{c}\text { Maximum } \\
\text { statistic }\end{array}$ & $\begin{array}{c}5 \% \\
\text { critical values }\end{array}$ \\
\hline 0 & 45.1691 & 29.68 & 35.1135 & 20.97 \\
1 & $10.0556^{*}$ & 15.41 & 8.5108 & 14.07 \\
2 & 1.5448 & 3.76 & 1.5448 & 3.76 \\
\hline
\end{tabular}

${ }^{\star} P<0.1$.

Table 8. South Africa model, Johansen tests for co-integration.

\begin{tabular}{ccccc}
\hline $\begin{array}{c}\text { Maximum } \\
\text { rank }\end{array}$ & $\begin{array}{c}\text { Trace } \\
\text { statistic }\end{array}$ & $\begin{array}{c}5 \% \\
\text { critical value }\end{array}$ & $\begin{array}{c}\text { Maximum } \\
\text { statistic }\end{array}$ & $\begin{array}{c}5 \% \\
\text { critical value }\end{array}$ \\
\hline 0 & 30.93 & 29.68 & 20.079 & 20.97 \\
1 & $10.85^{*}$ & 15.41 & 10.423 & 14.07 \\
2 & 0.43 & 3.76 & 0.4313 & 3.76 \\
\hline
\end{tabular}

${ }^{*} P<0.1$. 
Unlike Botswana and Namibia, the results show that both $\lambda$-maximum test value and trace test value are less than their critical values for one maximum rank of in the case of Zimbabwe, indicating that the null hypothesis of no cointegration among economic growth, exports and imports cannot be rejected. This means that there is one co-integration equation in the Zimbabwe model (Table 9).

Overall, a co-integration relationship exists between economic growth, exports, and imports for each case study, except from South Africa. We further check the joint long-run equilibrium relationship for the panel of the four sample countries. To that end, the null hypothesis is that: "there is no co-integration" and the alternative hypothesis is that "all panels are co-integrated". Judging by the probability values obtained, which are all less than $5 \%$ (see Table 10), we are to reject the null hypothesis for both equations considered in this case (GDP growth equation and Imports equation) and accept the alternative hypothesis. As such, we establish co-integration in the model. In other words, the three variables are cointegrated for the panel of four countries, implying that they have a long-run relationship.

Based on the results of co-integration tests for the sample of these countries, we can then run the Vector Error Correction Model (VECM) for Botswana, Namibia and Zimbabwe meanwhile, VAR model can be run for only South Africa.

Table 9. Zimbabwe model, Johansen tests for co-integration.

\begin{tabular}{ccccc}
\hline $\begin{array}{c}\text { Maximum } \\
\text { rank }\end{array}$ & $\begin{array}{c}\text { Trace } \\
\text { statistic }\end{array}$ & $\begin{array}{c}5 \% \\
\text { critical value }\end{array}$ & $\begin{array}{c}\text { Max } \\
\text { statistic }\end{array}$ & $\begin{array}{c}5 \% \\
\text { critical values }\end{array}$ \\
\hline 0 & 29.68 & 22.4471 & 14.899 & 20.97 \\
1 & $7.5474^{\star}$ & 15.41 & 5.1827 & 14.07 \\
2 & 2.3647 & 3.76 & 2.3647 & 3.76 \\
\hline
\end{tabular}

${ }^{*} P<0.1$.

Table 10. Kao co-integration test.

\begin{tabular}{ccccc}
\hline \multirow{2}{*}{ Dependent variables } & \multicolumn{2}{c}{ Economic growth } & \multicolumn{2}{c}{ Imports (M) } \\
\cline { 2 - 5 } & Statistics & $P$-value & Statistic & $P$-value \\
\hline Modified Dickey-Fuller t & $-4.226^{\star * *}$ & 0.000 & $-4.4939^{\star * *}$ & 0.000 \\
Dickey-Fuller t & $-2.087^{\star *}$ & 0.018 & $-2.234^{\star *}$ & 0.0127 \\
Augmented Dickey-Fuller t & $-2.607^{\star * *}$ & 0.004 & $-2.334^{\star * *}$ & 0.0098 \\
Unadjusted modified Dickey-Fuller t & $-4.179^{\star * *}$ & 0.000 & $-4.422^{\star * *}$ & 0.000 \\
Unadjusted Dickey-Fuller t & $-2.076^{\star *}$ & 0.019 & $-2.218^{\star *}$ & 0.0133
\end{tabular}

$\mathrm{Nb}$ of panel: 4 ; $\mathrm{Nb}$ of obs. 38

*** $P<0.01,{ }^{* *} P<0.05,{ }^{*} P<0.1$. 
In the short run, both the first lag and second lag of imports have no impacts on the growth in Botswana. The first lag and second lag of exports have no effect on the economic growth either. Similarly, both first lag and second lag of GDP have no effect on the exports; first lag and second lag of imports have no impact on exports either. The first lag of GDP and the second lag of exports have negative impact on imports at the $5 \%$ and $1 \%$ levels, respectively.

The results of the long-run equations show that for the first Equation (GDP), exports have a positive effect on GDP in the long-run. Such an impact is significant at the $1 \%$ level. On the contrary, the outcomes for the second Equation (imports) reveal that GDP has a negative impact on the imports at the $1 \%$ level. As for the GDP equation, imports have no effect on the GDP in the long-run. Exports have a positive effect on the imports at the $1 \%$ level while imports have no impact on the exports. In addition, GDP has a positive effect on exports.

Based on the outcomes, the empirical form of the co-integration equation for GDP, referred to as long-run model that derives from Equation (8) can be written for Botswana as follows:

$$
E C T=\left[1.00 G D P_{t-1}+0.040 M_{t-1}-2.003 X_{t-1}+2.5 \times 10^{9}\right]
$$

This finding, with the coefficients, which are statistically significant at the $1 \%$ level for exports, suggests that, in the long-run, exports have a positive effect on GDP in Botswana, while imports have a negative impact, and even no significant impact on GDP. In other words, an increase in the value of exports of goods and services in Botswana will result into an increase of the growth, while an increase in the imports may lead to a decrease of the growth. The adjustment term (0.059) is not statistically significant. However, the sign of the coefficient suggests that previous year's errors are corrected for within the current year at a convergence speed of $5.9 \%$.

As for Namibia, both exports and imports of goods and services have no effect on growth in the short run. Likewise, both GDP and exports have no significant effect on imports; GDP has positive impact on the exports, while imports negatively lead to exports at the $1 \%$ level. The outcomes indicate that the adjustment coefficient of the first Equation (GDP) for the short-term, though not statistically significant, indicates that previous year's deviation from long-run equilibrium are corrected for within the current year at a convergence speed of $3.8 \%$. In the long-run, imports have a positive and significant impact on the growth at the $1 \%$ level; GDP has a positive impact on imports. Exports have a positive effect on growth; such an impact is significant at the $1 \%$ level. GDP also has a positive and significant effect on exports, at the significant level of $1 \%$. Exports have negative and significant impacts on imports; conversely, imports also have a negative and significant impact on exports. The positive and significant effects of both imports and exports on GDP in the long run, imply that an increase in imports and exports would lead to an increase in Namibian economic growth in the long term. 
In the case of South Africa, neither the first lag nor the second lag of imports has significant effect on the GDP. Likewise, both first lag and second lag of exports reveal no significant impact on the country's economic growth. Similar results are found for both imports and exports equations, where there is no significant effect of GDP and exports on imports on one hand; and on the other hand, it emerges that GDP and imports have no impact on exports in South Africa. Moreover, it should be noticed that there is no long relationship between imports, exports and growth, based on the tests of co-integration.

In Zimbabwe, neither imports nor exports have significant effect on growth. The second lag of GDP and that of exports have positive and negative impacts, respectively on imports. The effects of GDP and imports are not significant on exports. In the long-run, imports have a negative but significant (5\% level) impact on growth; likewise, GDP also has a negative and significant effect on imports. Exports have positive effect on growth; such an impact is statistically significant at the $1 \%$ level. Same effect is observed from GDP to exports; exports have positive and significant impact on imports of goods and services. Likewise, imports have reciprocal positive effects on exports at the significant level of $1 \%$. Referred to the adjustment coefficient of GDP equation, though not significant, it reveals that previous year's errors are corrected for within the current year at a convergence speed of $10 \%$.

\subsection{The Direction of Causality}

In this section, we try to figure out for each country under investigation in the present study, whether: 1) imports cause economic growth or economic growth causes imports; 2) exports cause growth or growth causes exports of goods and services; 3 ) exports cause imports or imports cause exports. To get there, the null hypothesis of the GDP equation is that: "imports do not cause economic growth", and the alternative hypothesis is: "imports cause economic growth".

In the case of Botswana, the results revealed that the past values of both GDP and exports negatively forecast future values of imports of goods and services in the short run. In addition, the results showed that there is a unidirectional causality relation running from exports to growth in the long-run, and a feedback causality between exports and economic growth in Botswana, meaning a bidirectional causality between exports and economic growth (Table 11).

In Namibian economy, results show that the economic growth causes exports in the short run. In addition, the results reveal that there is a unidirectional causality relation running from imports to economic growth in the long run, and feedback causality between imports and economic growth. Likewise, our findings also show the unidirectional long-run causality from exports to growth, which, reports a feedback. These results are supported by the ILG, GLI, ELG and GLE models, indicating bidirectional causality on the one hand, between imports and GDP and, between exports and GDP, on the other hand (Table 12).

For South Africa, the granger causality test (Table 13) reveals that exports 
Table 11. Johansen normalization restriction imposed (Botswana).

\begin{tabular}{|c|c|c|c|c|}
\hline \multicolumn{5}{|c|}{ Equation (1) (GDP) } \\
\hline Beta & Coef. & Std. errors & $\mathrm{Z}$ & $P$-value \\
\hline GDP & 1 & & & \\
\hline imports & 0.040 & 0.191 & 0.21 & 0.832 \\
\hline Exports & $-2.003^{\star * *}$ & 0.229 & -8.71 & 0.000 \\
\hline Constant & $2.50 \mathrm{e}+09$ & & & \\
\hline \multicolumn{5}{|c|}{ Equation (2) (IMPORTS) } \\
\hline Beta & Coef & Std. errors & $\mathrm{Z}$ & $P$-value \\
\hline Imports & 1 & & & \\
\hline Exports & $-49.47^{\star \star \star}$ & 5.870 & -8.43 & 0.000 \\
\hline GDP & $24.69^{\star * *}$ & 3.367 & 7.33 & 0.000 \\
\hline Constant & $6.17 e+10$ & & & \\
\hline \multicolumn{5}{|c|}{ Equation (3) (EXPORTS) } \\
\hline Beta & Coef. & Std. errors & $\mathrm{Z}$ & $P$-value \\
\hline Exports & 1 & & & \\
\hline Imports & -0.020 & 0.094 & -0.21 & 0.831 \\
\hline GDP & $-0.499^{* * *}$ & 0.065 & -7.62 & 0.000 \\
\hline Constant & $-1.25 \mathrm{e}+09$ & & & \\
\hline
\end{tabular}

Table 12. Johansen normalization restriction imposed (Namibia).

\begin{tabular}{ccccc}
\hline \multicolumn{5}{c}{ Equation (1) } \\
\hline Beta & Coef. & Std. errors & $\mathrm{Z}$ & $P$-value \\
\hline GDP & 1 & & -7.48 & 0.000 \\
imports & $-0.840^{* * *}$ & 0.113 & -17.51 & 0.000 \\
Exports & $-0.807^{* * *}$ & 0.046 & & \\
Constant & $-1.29 \mathrm{e}+09$ & & & \\
& & & & \\
Beta & Coef & Std. errors & $\mathrm{Z}$ & \\
Imports & 1 & & & 0.000 \\
Exports & $1.041^{* * *}$ & 0.204 & & 0.000 \\
GDP & $-1.238^{* * *}$ & 0.073 & & \\
Constant & $1.60 \mathrm{e}+09$ & & & \\
\hline
\end{tabular}




\section{Continued}

\begin{tabular}{ccccc}
\hline & \multicolumn{3}{c}{ Equation (3) } \\
Beta & Coef. & Std. errors & $\mathrm{Z}$ & $P$-value \\
Exports & 1 & & & \\
Imports & $0.961^{* * *}$ & 0.116 & 8.30 & 0.000 \\
GDP & $-1.190^{* * *}$ & 0.100 & -11.89 & 0.000 \\
Constant & $1.54 \mathrm{e}+09$ & & & \\
\hline
\end{tabular}

${ }^{* *} P<0.01,{ }^{* *} P<0.05,{ }^{*} P<0.1$.

Table 13. Granger causality wald tests for South Africa.

\begin{tabular}{ccccc}
\hline Equations & Excluded & Chi2 & df & Prob > Chi2 \\
\hline GDP & Imports & 4.564 & 2 & 0.102 \\
GDP & Exports & 5.962 & 2 & 0.051 \\
GDP & All & 9.033 & 4 & 0.060 \\
Imports & GDP & 9.676 & 2 & 0.008 \\
Imports & Exports & 0.983 & 2 & 0.612 \\
Imports & All & 13.607 & 4 & 0.009 \\
Exports & GDP & 1.288 & 2 & 0.525 \\
Exports & Imports & 2.481 & 2 & 0.289 \\
exports & All & 2.904 & 4 & 0.574 \\
\hline
\end{tabular}

causes GDP, meanwhile imports does not cause growth. Overally, both imports and exports jointly cause economic growth at the $10 \%$ significance level. As for imports equation, the results show that GDP Granger causes imports, contrary to exports, which does not cause imports. In addition, our findings indicate that both GDP and exports jointly cause imports in South Africa. When it comes to exports equation, the outcomes do not show any evidence of causality of GDP and imports on the exports. These outcomes imply that there is unidirectional causality running from exports to GDP; likewise, a unidirectional causality running from GDP to imports, while there is no causal effect between exports and imports.

We find that, in Zimbabwe, there is unidirectional causality from GDP to imports in the short run, implying that the GLI model is validated, for the short run. In the long-run, we find exports cause growth and growth causes exports, a bidirectional causality between exports and growth, which is supported by GLE and ELG hypotheses. Similarly, we find that imports cause exports and exports cause imports, indicating bidirectional causality between exports and imports (Table 14). 
Table 14. Johansen normalization restriction imposed (Zimbabwe).

\begin{tabular}{|c|c|c|c|c|}
\hline & coef. & Std. errors & $\mathrm{Z}$ & $P$-value \\
\hline & & Equation (1) & & \\
\hline \multicolumn{5}{|l|}{ Beta } \\
\hline GDP & 1 & & & \\
\hline imports & $1.76 \mathrm{e}-07^{\star \star \star}$ & $9.35 e-08$ & -3.47 & 0.001 \\
\hline Exports & $-3.25 e-07$ & $1.76 \mathrm{e}-07$ & 1.00 & 0.316 \\
\hline Constant & -729.508 & & & \\
\hline \multicolumn{5}{|c|}{ Equation (2) } \\
\hline Beta & Coef & Std. errors & $\mathrm{Z}$ & $P$-value \\
\hline Imports & 1 & & & \\
\hline Exports & -0.570 & 0.681 & -0.84 & 0.402 \\
\hline GDP & -2863971 & 4640271 & -0.62 & 0.537 \\
\hline Constant & $2.10 \mathrm{e}+09$ & & & \\
\hline \multicolumn{5}{|c|}{ Equation (3) } \\
\hline Beta & Coef. & Std. errors & $\mathrm{Z}$ & $P$-value \\
\hline Exports & 1 & & & \\
\hline Imports & $-1.88819^{\star \star \star *}$ & 0.4781557 & -3.95 & 0.000 \\
\hline GDP & 6004014 & 6119496 & 0.98 & 0.327 \\
\hline Constant & $-4.37 e+09$ & & & \\
\hline
\end{tabular}

${ }^{\star * *} P<0.01,{ }^{*} P<0 . * P<0.1$.

\subsection{Post Estimation Tests}

To ensure that the errors are normally distributed and our models are stable, to ensure that there is no autocorrelation, we performed some diagnostics. Hence, for the four countries under investigation, autocorrelation test, test of Normality and model stability test were sequentially carried out.

In the case of Botswana, the results of autocorrelation diagnostics showed that, even at the lag one or lag two, the errors are not correlated, which is good for our estimates. The results of Jacque-Bera test revealed that the errors are normally distributed for each of the three equations that make up the entire $V E C M$ system; and overall, the errors are normally distributed for the VECM model in case of Botswana. As for the Stability of the model, the VECM specification imposes two unit moduli. In the case of Namibia, with the outcomes of lagrange-multiplier test results, we fail to reject the null hypothesis of no autocorrelation, meaning that the residuals are not correlated. Hence, this model is good. Looking at the normality test results, the errors for the three equations are normally distributed, based on the P-values of Jacque-Bera test. As has been seen in Botswana, the VECM specification in Namibia also imposes two unit moduli. 
The South Africa case also shows that the $P$-value of the autocorrelation test is greater than 0.05 , meaning that both first lag and second lag are free from autocorrelation. Notably, the errors of the GDP, imports and exports equations are all normally distributed. Moreover, the eigenvalues lie inside the unit circle, implying that the $V A R$ model used for South Africa satisfies stability condition. In the case of Zimbabwe, we cannot reject the null hypothesis that there is no autocorrelation between the residuals, given the $P$-value is greater $5 \%$. Such finding indicates that the residuals are not correlated. The outcomes of Jacque-Bera test revealed that the errors are normally distributed for each of GDP, imports and exports equation and that of the entire $V E C M$ system for Zimbabwe. The test checking the $V E C M$ model stability for Zimbabwe shows similar findings as that of Botswana and Namibia where the model specification imposes two unit moduli.

\section{Discussion}

The relationship between trade openness and growth, which has being receiving greater attention since the last two decades, is considered a controversial one in the economic literature. Considering the difference in economic performance especially between the developing countries, understanding the causal link between imports, exports and economic growth is crucial from a policy perspective. To start our empirical analysis, export, import, and GDP are found stationary at the first differences. Thus, the variables were found to be integrated of order one for the panel of four countries considered in this study. The subsequent co-integration test confirmed that except from South Africa, GDP, exports, and imports are co-integrated in the countries under investigation. This finding therein indicates the existence of a long-run equilibrium relationship between the variables (GDP, import, and export) confirmed by the Johansen co-integration test results for Botswana, Namibia and Zimbabwe.

Furthermore, the current study investigated the causal relationship between GDP, imports and exports. First, the results revealed, with respect to short run causality, a unidirectional causality relation running from growth to exports that was found in case of Namibia. Such result that confirms the GLE hypothesis is comparable to the findings by Hatemi and Irandoust (2000). Indeed, they demonstrated evidence of unidirectional Granger causality that runs from economic growth to export growth in Denmark. Later, Nguyen and Wongsurawat (2017) found similar results for the Vietnamese economy. Secondly, the result of the unidirectional causality running from exports to GDP illustrates the ELG hypothesis. This finding agrees with those of previous studies (e.g. Mehrara et al., 2012; Saad, 2012; Mamun et al., 2019; Maitra, 2020). Recently, Dudzevičiūtè et al. (2021) have demonstrated the same unidirectional causality running from export to economic growth in Asia, Europe, North America and Oceania.

Thirdly, our finding of the unidirectional causality that runs from GDP to imports in the case of South Africa and that of Zimbabwe, both in the short run 
is in line with the study by Chang et al. (2014). Their empirical results support the unidirectional causality from growth to imports for four out of nine provinces investigated in South Africa. Aluko and Adeyeye (2020) pointed out a unidirectional causality running from economic growth to imports both in the short-run and long-run, in a few countries out of the 41 countries investigated.

Our results further indicate a bidirectional causality between exports and economic growth in the long run for Botswana, Namibia and Zimbabwe, supporting the ELG and GLE hypotheses; Dritsakis and Stamatiou (2018) also found similar bidirectional causality between economic growth and exports for the old European Union members. In addition, our findings showed the existence of bidirectional causality between imports and GDP in Namibia in the long-run, indicating evidence supporting the ILG and GLI hypotheses. Maitra (2020) reported prominent evidence of ILG hypothesis, both in the short and long run in India, suggesting that import is a significant bearing of economic growth.

More interestingly, our results revealed a bidirectional causality between imports and exports for Zimbabwe in the long run. This is comparable to the work by Vardari (2015) which argues for unidirectional Granger causality that runs from import to exports in Kosovo and a unidirectional causality running from exports to import. Possible explanation for our finding is that an increase in exports value could lead to increased foreign currency inflows. In return, the country's capability would also increase, resulting in its value of imports of goods and services. Thereafter, an increase in the value of imports could be beneficial for local firms and the entire country. Indeed, imports boost productivity through their competitive impact. Imports provide firms with access to better, cheaper, and domestically unavailable inputs and equipment. They consequently stimulate productivity and reduce production costs making the production of new goods both possible and profitable (Romer, 1986). In addition, imports abet access to foreign technology because foreign technology is embodied in imported inputs and equipment. Thus, domestic firms' production capacity hence their exports will increase.

\section{Conclusion}

The contribution of exports to a country's economic growth and development is highly recognized in both theoretical and empirical literature. Success in economic growth of many Southern African countries has been significantly and partly attributed to their exporting activities. Southern African economies have a large share of exports of raw materials and commodities in their GDP. At the same time, these countries heavily depend on imports of various goods and services. Exports are basically made of natural resources while most of their imports consist of a wide range of goods and services. The aim of this study was to explain the nexus between exports, imports and economic growth of a sample of four countries in Southern Africa for the period 1980-2019. The specific objectives of the study were to 1 ) determine whether imports, exports and economic 
growth are correlated in a long run or a short run in Botswana, Namibia, South Africa and Zimbabwe; 2) determine if imports and exports affect positively or negatively economic growth in Botswana, Namibia, South Africa and Zimbabwe. To this end, we employed time series data for each country investigated. In doing so, the co-integration, Vector Autoregressive "VAR" model (for South Africa) and vector error correction models " $V E C M$ " model (for Botswana, Namibia and Zimbabwe) then the Granger causality tests were applied to investigate the relationship between these three variables. The unit root properties of the data were examined using the Augmented Dickey Fuller test (ADF) and thereafter, the co-integration and causality tests were conducted.

The results show that both the short run and long run relationships exist among these variables. On one hand, our findings failed to validate the export-led growth hypothesis for South Africa in the long-run but provided support for the exports-led growth hypothesis in the short-run. Similarly, our results provide support for the export-led growth hypothesis for three countries in the long run. In other words, these results suggest that within the entire sample period (19802019) the export-led growth hypothesis holds for Botswana, Namibia, and Zimbabwe. Likewise, the results show evidence for growth-led exports hypothesis for these three countries, implying bidirectional causality between exports and growth for Botswana, Namibia, and Zimbabwe. On the other hand, a suggestive evidence of unidirectional causality running from growth to imports was found in the case of Botswana, Namibia and South Africa. In addition, only Namibia case study confirmed the imports-led growth hypothesis in the long run. Finally, bidirectional causality between exports and imports was validated by Zimbabwe's case study.

One of the major limitations of this study was its small sample size (four countries). Indeed, the data have limitations as it is only for the period 19802019. In addition, the data are restricted only to secondary sources.

Despite its limitations, this study suggests that for growth to be increased, the developmental actions in the Southern African countries should review their "economic growth drivers". Such actions suggest that current policies in this regard need to be revisited and strengthened. Key implications are that the exports development could create employment opportunities and other spillovers. Consequently, policy makers in Southern African nations should act together to grow all the more effectively their policies. Policy-makers should improve and strengthen the competiveness of export sector.

\section{Acknowledgements}

The authors would like to thank the anonymous reviewers whose comments and suggestions helped improve the manuscript.

\section{Conflicts of Interest}

The authors declare no conflicts of interest regarding the publication of this paper. 


\section{References}

Abdulla, S., \& Ali, H. (2019). An Analysis of Exports and Imports and Their Effect on the Economic Growth in Iraq. UKH Journal of Social Sciences, 3, 68-76. https://doi.org/10.25079/ukhjss.v3n2y2019.pp68-76

Acemoglu, D., Johnson, S. H., \& Robinson, J. A. (2001). An African Success Story: Botswana. SSRN Electronic Journal.

AfDB (2013). Botswana Economic Outlook. http://www.afdb.org/en/countries/southern-africa/botswana/botswana-economic-outlo ok/

AfDB (2021). Botswana Economic Outlook. The African Development Bank. https://www.afdb.org/en/countries/southern-africa/botswana/botswana-economic-outl ook\#: :text=Botswana's\%20economy\%20contracted\%20by\%20an,falling\%20global\%20 demand\%20for\%20diamonds

Ahmed, J., \& Kwan, A. C. (1991). Causality between Exports and Economic Growth. Economics Letters, 37, 243-248. https://doi.org/10.1016/0165-1765(91)90218-A

Alam, K. J., \& Sumon, K. K. (2020). Causal Relationship between Trade Openness and Economic Growth: A Panel Data Analysis of Asian Countries. International Journal of Economics and Financial Issues, 10, 118-126. https://doi.org/10.32479/ijefi.8657

Aluko, O. A., \& Adeyeye, P. O. (2020). Imports and Economic Growth in Africa: Testing for Granger Causality in the Frequency Domain. The Journal of International Trade \& Economic Development, 29, 850-864. https://doi.org/10.1080/09638199.2020.1751870

Aluko, O. A., \& Obalade, A. A. (2020). Import-Economic Growth Nexus in Selected African Countries: An Application of the Toda-Yamamoto Granger Non-Causality Test. Zagreb International Review of Economics and Business, 23, 117-128. https://doi.org/10.2478/zireb-2020-0016

Andrew, B., Eaton, J., Jensen B., \& Kortum, S. (2003). Plants and Productivity in International Trade. The American Economic Review, 93, 1268-1290. https://doi.org/10.1257/000282803769206296

Arize, A. (2002). Imports and Exports in 50 Countries: Tests for Cointegration and Structural Breaks. International Review of Economics and Finance, 11, 101-115. https://doi.org/10.1016/S1059-0560(01)00101-0

Arodoye, N. L., \& Iyoha, M. A. (2014). Foreign Trade-Economic Growth Nexus: Evidence from Nigeria. CBN Journal of Applied Statistics, 5, 121-141.

Awokuse, T. O. (2005). Exports, Economic Growth and Causality in Korea. Applied Economics Letters, 12, 693-696. https://doi.org/10.1080/13504850500188265

Bakari, S., \& Krit, M. (2017). The Nexus between Exports, Imports and Economic Growth: Evidence from Mauritania. International Journal of Economics and Business Research, $5,10-17$.

Beny, L. N., \& Cook, L. D. (2009). Metals or Management? Explaining Africa's Recent Economic Growth Performance. American Economic Review, 99, 268-274. https://doi.org/10.1257/aer.99.2.268

Bigsten, A., Collier, P., Dercon, S., Fafchamps, M., Gauthier, B., Willem Gunning, J., Oduro, A., Oostendorp, R., Pattillo, C., \& Söderbom, M. (2004). Do African Manufacturing Firms Learn from Exporting? The Journal of Development Studies, 40, 115-141. https://doi.org/10.1080/0022038042000213229

Bonga, W. G., Shenje, T. E., \& Sithole, R. (2015). Export Sector Contribution to Economic Growth in Zimbabwe: A Causality Analysis. The International Journal of Business and 
Management, 3, 452-464.

http://internationaljournalcorner.com/index.php/theijbm/article/view/138108

Chang, T., Simo-Kengne, B. D., \& Gupta, R. (2014). The Causal Relationship between Imports and Economic Growth in the Nine Provinces of South Africa: Evidence from Panel Granger Causality Tests. Journal of Economic Cooperation and Development, 35, 71-90. https://doi.org/10.1504/IJSE.2014.065389

Coe, D. T., \& Helpman, E. (1995). International R\&D Spillovers. European Economic Review, 39, 859-887. https://doi.org/10.1016/0014-2921(94)00100-E

Deme, M. (2002). An Examination of the Trade-Led Growth Hypothesis in Nigeria: A Cointegration, Causality and Impulse Response Analysis. The Journal of Developing Areas, 36, 1-15.

Dodaro, S. (1991). Comparative Advantage, Trade and Growth: Export Led-Growth Revisited. World Development, 19, 1153-1165.

https://doi.org/10.1016/0305-750X(91)90064-O

Dritsakis, N., \& Stamatiou, P. (2018). Causal Nexus between FDI, Exports, Unemployment and Economic Growth for the Old European Union Members. Evidence from Panel Data. International Journal of Economic Sciences, 2, 35-56.

https://doi.org/10.20472/ES.2018.7.2.002

Dudzevičiūtè, G., Šimelytė, A., \& Giedraitytè, V. (2021). Export-Economic Growth Nexus in the World Regions: Directions of Public Policy. Public Policy and Administration, 20, 98-107. https://doi.org/10.5755/j01.ppaa.20.1.28500

Feenstra, R. C., Inklaar, R., \& Timmer, M. (2013). The Next Generation of the Penn World Table. http://www.nber.org/papers/w19255

Grossman, G. M., \& Helpman, E. (1991). Innovation and Growth: Technological Competition in the Global Economy. The MIT Press.

Hallaert, J. J. (2014). Importing Growth: The Crucial Role of Imports in a Trade-Led Growth Strategy (August 18, 2014). GEM Policy Brief.

Hassan, S., \& Murtala, M. (2016). Market Size and Export-Led Growth Hypotheses: New Evidence from Malaysia. International Journal of Economics and Financial Issues, 6, 971-977.

Hatemi-J, A., \& Irandoust, M. (2000). Export Performance and Economic Growth Causality: An Empirical Analysis. Atlantic Economic Journal, 28, 412-426.

Herzer, D. (2007). How Does Trade Composition Affect Productivity? Evidence for Chile. Applied Economics Letters, 14, 909-912. https://doi.org/10.1080/13504850600690012

Hur, J., \& Park, C. (2012). Do Free Trade Agreements Increase Economic Growth of the Member Countries? World Development, 40, 1283-1294.

https://doi.org/10.1016/j.worlddev.2011.12.006

Hussain, M., \& Saaed, A. A. J. (2014). Export and GDP in Pakistan: Evidence from Causality and Co-Integration Analysis. International Journal of Management Cases, 16, 37-46.

Husted, S. (1992). The Emerging US Current Account Deficit in the 1980s: A Cointegration Analysis. Review of Economics and Statistics, 74, 159-166.

https://doi.org/10.2307/2109554

Hye, Q. M. A. (2012). Exports, Imports and Economic Growth in China: An ARDL Analysis. Journal of Chinese Economic and Foreign Trade Studies, 5, 42-55. https://doi.org/10.1108/17544401211197959

Jan, D., Ahmad, M., \& Ullah, S. (2019). Impact of Exports and Imports on Economic 
Growth in Case of Pakistan. International Journal of Information, Business and Management, 11, 142-156.

Jones, R. W. (2008). Heckscher-Ohlin Trade Flows: A Re-Appraisal. In The New Palgrave Dictionary of Economics. Palgrave Macmillan. https://doi.org/10.1057/978-1-349-95121-5_1116-2

Jung, W. S., \& Marshall, P. J. (1985). Exports, Growth and Causality in Developing Countries. Journal of Development Economics, 18, 1-12. https://doi.org/10.1016/0304-3878(85)90002-1

Katircioglu, S., Eminer, F., Aga, M., \& Ozyigit, A. (2010). Trade and Growth in the Pacific Islands: Empirical Evidence from the Bound Test to Level Relationship and Granger Causality Tests. Romanian Journal of Economic Forecasting, 4, 88-101.

Lam, T. D. (2016). An Empirical Analysis of the ASEAN-4's Causality between Exports and Output Growth. International Journal of Economics and Financial Issues, 6, 497-502.

Lin, J. Y., \& Li, Y. (2003). Export and Economic Growth in China: A Demand-Oriented Analysis. China Economic Quarterly, 2, 779-794.

Maitra, B. (2020). Exploring Import-Led Growth in India: Evidence from the Post-Reform Period. South Asian Journal of Macroeconomics and Public Finance, 9, 87-113. https://doi.org/10.1177/2277978720906068

Mamun, A., Bal, H., \& Akca, E. E. (2019). The Export-Output Growth Nexus in Bangladesh: A Leveraged Bootstrap Approach. Journal of Asia Business Studies, 13, 196-213. https://doi.org/10.1108/JABS-09-2017-0159

Manwa, F., Wijeweera, A., \& Kortt, M. A. (2019). Trade and Growth in SACU Countries: A Panel Data Analysis. Economic Analysis and Policy, 63, 107-118. https://doi.org/10.1016/j.eap.2019.05.003

Mehrara, M., Haghnejad, A., Dehnavi, J., \& Meybodi, F. J. (2012). Dynamic Causal Relationships among GDP, Exports, and Foreign Direct Investment (FDI) in the Developing Countries. International Letters of Social and Humanistic Sciences, 14, 1-19. https://doi.org/10.18052/www.scipress.com/ILSHS.14.1

Mehta, N. S. (2015). The Dynamics of Relationship between Exports, Imports and Economic Growth in India. International Journal of Research in Humanities \& Social Sciences, 3, 39-47.

Melitz, M. J. (2003). The Impact of Trade on Intra-Industry Reallocations and Aggregate Industry Productivity. Econometrica, 71, 1695-1725. https://doi.org/10.1111/1468-0262.00467

Nguyen, T. N., \& Wongsurawat, W. (2017). Multivariate Co-Integration and Causality between Electricity Consumption, Economic Growth, Foreign Direct Investment and Exports: Recent Evidence from Vietnam. International Journal of Energy Economics and Policy, 7, 287-293.

Ogbokor, C. A., \& Meyer, M. D. (2016). An Econometric Time-Series Analysis of the Dynamic Relationship between Foreign Trade and Economic Growth in a Developing Country: Evidence from Namibia. Acta Universitatis Danubius Oeconomica, 12, 153-170.

Reddy, K. K. (2020). Exports, Imports and Economic Growth in India: An Empirical Analysis. Theoretical and Applied Economics, XXVII, 323-330.

Rivera-Batiz, L., \& Romer, P. M. (1991). Economic Integration and Endogenous Growth. Quarterly Journal of Economics, 106, 531-555. https://doi.org/10.2307/2937946

Romer, P. M. (1986). Increasing Returns and Long-Run Growth. Journal of Political Economy, 94, 1002-1037. https://doi.org/10.1086/261420 
Saad, W. (2012). Causality between Economic Growth, Export, and External Debt Servicing: The Case of Lebanon. International Journal of Economics and Finance, 4, 134-143. https://doi.org/10.5539/ijef.v4n11p134

Saaed, A. A. J., \& Hussain, M. A. (2015). Impact of Exports and Imports on Economic Growth: Evidence from Tunisia. Journal of Emerging Trends in Economics and Management Sciences (JETEMS), 6, 13-21.

Sato, S., \& Fukushige, M. (2007). The End of Import-Led Growth? North Korean Evidence. Discussion Papers in Economics and Business Discussion Paper, 07-38.

Shah, S. A. Y., Ahmad, N., Aslam, W., \& Subhani, B. H. (2020). An Analysis of the Relationships among Exports, Imports, Physical Capital and Economic Growth in Pakistan. Journal of Quantitative Methods, 4, 1. https://doi.org/10.29145/2020/jqm/040105

Shan, J., \& Sun, F. (1998). On the Export-Led Growth Hypothesis: The Econometric Evidence from China. Applied Economics, 30, 1055-1065. https://doi.org/10.1080/000368498325228

Simasiku, C., \& Sheefeni, J. P. S. (2017). Agricultural Exports and Economic Growth in Namibia. European Journal of Basic and Applied Sciences, 4, 41-50.

Siphambe, H. K., Narayana, N., Akinkugbe, O., \& Sentsho, J. (2005). Economic Development of Botswana: Facets, Policies, Problems and Prospects. Bay Publishing.

Statistics Botswana (2019). International Merchandise Trade Statistics. http://www.statsbots.org.bw/sites/default/files/publications/International\%20Merchan dise\%20Trade\%20Statistics\%20\%20April\%202019.pdf

Stats SA (2021). GDP: Quantifying SA's Economic Performance in 2020. Republic of South Africa, Statistics South Africa. http://www.statssa.gov.za/?p=14074

Sulaiman, M., \& Saad, N. M. (2009). An Analysis of Export Performance and Economic Growth of Malaysia Using Co-Integration and Error Correction Models. The Journal of Developing Areas, 34, 217-231. https://doi.org/10.1353/jda.0.0031

Taniguchiy, M. (2018). The Effect of an Increase in Imports from China on Local Labor Markets in Japan. Journal of the Japanese and International Economies, 51, 1-18. https://doi.org/10.1016/j.jjie.2018.09.001

Toda, H. Y., \& Yamamoto, T. (1995). Statistical Inference in Vector Auto-Regressions with Possibly Integrated Processes. Journal of Econometrics, 66, 225-250. https://doi.org/10.1016/0304-4076(94)01616-8

Utonga, D., \& Dimoso, R. L. (2019). The Nexus between Export and Economic Growth in Tanzania. Journal of Business School, 2, 49-59. https://doi.org/10.26677/TR1010.2019.144

Van Biesebroeck, J. (2005). Exporting Raises Productivity in Sub-Saharan African Manufacturing Firms. Journal of International Economics, 67, 373-391. https://doi.org/10.1016/j.jinteco.2004.12.002

Vardari, L. M. (2015). Relationship between Import-Exports and Economic Growth: The Kosova Case Study. Revista Shkencore Regjionale (REFORMA), 3, 262-269. https://doi.org/10.2139/ssrn.2889731

Velnampy, T., \& Achchuthan, S. (2013). Export, Import and Economic Growth: Evidence from Sri Lanka. Journal of Economics and Sustainable Development, 4, 147-155.

Vijayasri, G. V. (2013). The Importance of International Trade in the World. International Journal of Marketing, Financial Services \& Management Research, 2, 111-119.

Werner Kristjanpoller, R., \& Olson, J. E. (2014). Economic Growth in Latin American Countries: Is It Based on Export-Led or Import-Led Growth? Emerging Markets Finance 
and Trade, 50, 6-20. https://doi.org/10.2753/REE1540-496X5001S101

Wood, A., \& Mayer, J. (2001). Africa's Export Structure in a Comparative Perspective. Cambridge Journal of Economics, 25, 369-394. https://doi.org/10.1093/cje/25.3.369

World Bank of South Africa (2021). Overview.

https://www.worldbank.org/en/country/southafrica/overview 